\title{
THE EFFECTIVENESS OF MULTIPLE INTELLIGENCES BASED TEACHING STRATEGY IN ENHANCING THE MULTIPLE INTELLIGENCES AND SCIENCE PROCESS SKILLS OF JUNIOR HIGH SCHOOL STUDENTS
}

\author{
Atiek Winarti ${ }^{1}$ iD, Leny Yuanita ${ }^{2}$ iD, Moh. Nur $^{2}$ iD \\ ${ }^{1}$ Universitas Lambung Mangkurat (Indonesia) \\ ${ }^{2}$ Universitas Negeri Surabaya (Indonesia) \\ atiekwin_kimia@ulm.ac.id, Yuanita@unesa.com,psmsunesa@yahoo.com
}

Received February 2018

Accepted August 2018

\begin{abstract}
This study is based on the low attention of teachers on students' potential compared to academic ability. Teachers' focus on academic ability as the sole determinant of successful learning causes learning to be incapable of developing the students' potential called Multiple Intelligences (MI), whereas they can be applied to make students enjoy learning as well as develop the potential and thinking skills of students. To overcome this problem, a teaching strategy based on Multiple Intelligences was developed in science lesson. The effectiveness of the teaching strategy was evaluated by pretest-posttest-control-group design. The samples consisted of 124 of junior high school students. Data were obtained from Multiple intelligences test, Science Process Skills (SPS) test, and observation sheets. The hypotheses were tested using t-test, simple linear regression, and one-way ANOVA. The study revealed that Multiple Intelligences strategy has an effect on and can be a significant predictor of the development of students' Multiple intelligences. This study showed an improvement of the SPS, specifically in the questioning ability. The results of this study will change the teaching strategy in the future, from academic ability oriented to be multiple intelligences oriented and focus on the potential of each student.
\end{abstract}

Keywords - Teaching strategy, Multiple Intelligences, Science Process Skills.

\section{To cite this article:}

Winarti, A., Yuanita, L., \& Nur, M. (2019). The effectiveness of multiple intelligences based teaching strategy in enhancing the multiple intelligences and Science Process Skills of junior high school students. Journal of Technology and Science Education, 9(2), 122-135. https://doi.org/10.3926/jotse.404

\section{Introduction}

Human intelligence is often defined narrowly as IQ (intelligences Quotient). Even, IQ is considered as a critical indicator of one's success, whereas the intelligence measured in IQ tests only includes language intelligence and mathematical logic. Intelligence is actually more than just language and logic intelligences. Gardner (1993) defines intelligence as the human ability to create problems and solve them. Hence, the kind of human intelligence will appear when a person faces a problem and solves it. Gardner (1993) and Armstrong (2004) stated that every human being has eight types of intelligences at different capacity. 
Identifying students' dominant types of intelligences before they start studying is important to assist teachers design appropriate strategies (Griggs, Barney, Brown-Sederberg, Collins, Keith \& Iannacci, 2009: page 55).

Since Gardner's publication of the Multiple Intelligences (MI) theory, several studies have investigated the implications of the theory to be applied in teaching and learning activities in various subjects, including language, psychology and science. Some studies conducted by Pociask and Settles (2007), Owolabi and Okebukola (2009), Chuang, Tsu and Tsao (2010), Abdi, Laei and Ahmadyan (2013), and Nurulwahida, Yaacob and Shaik-Abdullah (2014), suggest that multiple intelligence theory need to be applied in classrooms through various ways such as implementing brain-based learning strategy, study group method, video games, and modules. Furthermore, Yurt and Polat (2015), Madkour and Mohammed (2016) and Sánchez-Martín, Álvarez-Gragera, Dávila-Acedo and Mellado (2017) found that adjusting learning strategies with students' intelligence has improved learning motivation and emotional intelligence to positively impact student achievement. However, these previous studies tent to be more focus on the impact of learning strategies on learning achievements (Pociask \& Settles, 2007; Owolabi \& Okebukola, 2009; Othman, 2013; Abdi et al., 2013; Widiana \& Jampel, 2016). Only few studies have applied the theory of MI to enhance students' MI and Science Process Skills (SPS). Chuang et al. (2010) examines the efforts of increasing MI through video game applications and found that the use of video game puzzles can strengthen multiple intelligences of students.

This study aimed to investigate the effectiveness of MI-based learning strategies in enhancing the multiple intelligences and SPS of students. 124 junior high school students included as the samples. The development of MI-based learning strategy has not been reported in the previous studies. The characteristics of MI-based teaching strategy developed in this study can be seen from several aspects as follows:

(1) The learning strategy is designed to be relatively easier to apply than the MI-based strategy developed in the previous study. If the strategies developed in the previous researches are more complex and require considerable time, then the developed strategy is simpler without having to change the school's learning program. This simplification is expected to enable teachers to implement learning strategy without changing the school's system. In other words, this strategy can be applied by all teachers on all subjects according to the applicable curriculum.

(2) This strategy integrates interests and talents in formal learning to achieve mastery of sciences concepts and develop students' dominant intelligence. So far, interests and talents are not developed in a classroom, but in non-formal activities. Learning that integrates children's interest in the arts or sport to learn formal learning materials such as science in school is something new.

In this study, learning strategy is designed based on MI theory to improve not only students' achievement, but also multiple intelligence and SPS of students. Determination of MI and SPS as dependent variables due to these two variables are very important for students. A learning process which is designed in accordance with students' dominant types of intelligence will be more enjoyable for students (Yurt \& Polat, 2015; Madkour \& Mohammed, 2016)

The SPS are the unique skills resulted from science lesson. Padilla (1990) stated that students cannot be expected to excel at the skills if they have not experienced or been allowed to practice. Instead students need to be given opportunities to work with these skills in different content areas and contexts. By giving students repetitive exercises to train science process skill, they will be trained and mastered it.

The results of this study will change teaching strategies in the future from academic ability to MI oriented and focus on the potential of each student. It is expected to contribute to the improvement of the quality of science lesson, thus the science lessons will no longer aims to merely improve academic ability, but also develop students' thinking skills and potentials. 


\section{Basic Theories of the Developed Learning Strategy}

This learning strategy was developed based on Gardner theory of Multiple Intelligence (MI), Cognitive Developmental theory by Piaget, and Constructivism theory by Vygotsky. According to Gardner's theory (1993), intelligence is the human ability to create problems and solve them. The key of MI theory is that all human beings have eight intelligences that are independent each other with varying degrees. Based on the assumption that each individual's intelligence profile is not the same, then the learning can be developed by evaluating the students' intelligence profile and designing the learning activity based on the level of the intelligence. According to MI theory, the dominant intelligence of a child is generally relevant to the child's interest (Armstrong, 2004). Through this learning strategy, interests and talents serve as a means to learn the subject matter. Therefore, in application of this learning strategy, any type of student's dominant intelligence that may arise will be facilitated to evolve through appropriate activities, such as making songs for musical intelligence, writing poetry related to the subject matter for verbal linguistic intelligence, designing games or performing role playing for kinesthetic intelligence.

Piaget's cognitive development theory, one of these strategic bases, deals with several important concepts in the development of human cognitive levels such as intelligence, schemata, assimilation and accommodation and equilibrium (Santrock, 2004; Slavin, 2006; Hergenhahn \& Olson, 2009). Piaget defines intelligent action as an action leading to an optimal condition for the survival of the organism (Hergenhahn \& Olson, 2009: page 313). Furthermore, Vygotsky's theory (Slavin, 2006) believes that intellectuals develop when one faces a new experience with curiosity. In an effort to understand the new experience, individuals associate new knowledge with prior knowledge and build new meaning. Vygotsky believes that cognitive ability comes from social relations and is influenced by socio-cultural backgrounds. According to Vygotsky social interactions with others sparked the emergence of new ideas and enrich the intellectual development of students. This idea is the basis of collaborative learning, applied in this research with appropriate challenges and assistance from more capable teachers or peers, students move forward in their nearest development zone, where new learning takes place.

Application of MI theory in classroom activities has been reported by the other studies such as Owolabi and Okebokula (2009), Hanafin (2014), Ghamrawi (2014), Madkour and Mohammed (2016) and Sháncez-Martín et al. (2017). Those researches indicated that the implementation of MI-based learning strategies in schools not only improves learning outcomes but also students' interest, motivation, and emotional intelligence. Students' retention increases as the improvement of their self-esteem. Research conducted by Ghamrawi (2014) on the child's ability to learn vocabulary proved that the application of MI theory does not make children learn words faster, but improves children's retention in learning. However, the previous researches on multiple intelligences were more focused on the impact of the learning method toward students' interest, motivation, self esteem, and learning outcomes. There were only small amount researches on multiple intelligences that try to improve the multiple intelligences themselves. Researches by Chuang et al. (2010), Talib and Bini-Kailani (2014) tried to increase students' multiple intelligences, but they were only focus on one or two types of intelligences.

This article describes the results of experiment on the development of MI based teaching strategy implemented in science lesson. In the introduction section, the background of the research and the theoretical basic of the developed strategy are explained. The methodology describes about the research method, the sample, the research instrument, and the data analysis, while in the result and discussion, the dependent variables of the research, namely students' MI and SPS, will be discussed.

\section{Methodology}

This study employed quasi experimental research design. By using stratified random sampling, two schools were selected, the Public Junior High School (JHS) 1 representing high academic achievers and the Public JHS 24 representing low academic achievers based on the national exam score. In each school, 2 (two) classes were selected, 1 (one) control class was taught using traditional strategies such as lectures, demonstrations and group discussions, and 1 (one) experimental class was taught using strategies based on 
applied MI theory (strategy). The samples were 124 students selected from both schools. The experimental group and control group consisted of 63 and 61 students respectively as illustrated in Table 1. To avoid the bias, the control and experimental classes were taught by the same teachers. The teachers are those who used to teach in the schools.

The MI-strategy developed in this study was designed based on a series of instructional events by Gagne (1977). The MI-strategy consists of six stages namely (1) Self-reflection, where students tell about themselves, their study habits and hobbies, etc., (2) Introduction of concept by teachers, using activities which involve all aspects of MI, (3) Formulation of questions about the subject matter by the students, (4) Deepening the concept through SPS practices which involve all aspects of MI, (5) Expressing understanding on the concepts through activities which are appropriate with students' dominant types of intelligence, and (6) Concluding the lessons. The activities at stage (1) to (4) were carried out in a group with various dominant types of intelligence while activities at stage (5) were carried out in a group of students who have similar dominant intelligence. Then, activities at stage (6) were carried out individually. The characteristic of this learning strategy lies in step (5), in which students were grouped based on the dominant type of intelligence. In the group, they were asked to express their understanding on the subject matter in a way which they like most and appropriate to their dominant types of intelligence, such as designing games for students with linguistic and kinesthetic intelligence, composing music for students with musical intelligence, painting for students with visual-spatial intelligence, drawing a simple bouquet for students with intrapersonal intelligence, or planning a further study for students with logical-mathematical intelligence.

The traditional strategies applied in control class consisted of lecture, discussion, and demonstration method. The lesson began with teacher's questions. Then after explaining the lesson objective, the teacher explained the subject matter by using lecture and demonstration method. The students then worked together on the worksheet, discussed, and present it in the class. The lesson ended with formulating conclusions by the students under the teacher guidance.

The teaching and learning process was conducted for 12 weeks involving one teacher and five observers. The teacher taught using the specified teaching strategy, while the observers made observation of the teaching and learning process.

The Multiple Intelligences (MI) test developed by Gardner (1993), Armstrong (2004), McClellan and Conti (2008) was used to collect the data on students' MI. The instrument consists of 56 questions which are divided into 8 parts based on types of MI as follows, linguistic, kinesthetic, musical, visual-spatial, intrapersonal, interpersonal, logical-mathematical, and naturalist. The instrument applied Likert Scale, which each part contained 7 questions that have to be answered by selecting 4 options, namely; absolutely agree (score 4), agree (score 3), disagree (score 2), and absolutely disagree (score 1).

Data of students' SPS were collected by standard assessment test and observation sheets. In SPS test, students were tested by conducting 5 skills as follows: questioning, predicting, data analyzing, classifying, and concluding. The quality of these skills was assessed by a rubric. Science process skills were evaluated 3 times using three worksheets, each of which conducted after lesson 1, lesson 2, and lesson 3 . The quality of SPS instrument was determined by content validity and reliability test. The instrument was validated by 5 (five) validators who assess (1) the content, (2) the construction, and (3) the language of the instrument. Validity of the instrument is decided into three criteria; feasible, feasible by improvement, and not feasible. Reliability of the instrument was assessed using Interrater Consistency (Linn \& Gronlund, 2009). The calculation of the reliability test used intra-class correlation coefficient (ICC). Based on the ICC score, the criteria of the reliability can be classified as follow (Streiner \& Norman, 2000).

Based on the validator judgment, the SPS assessment instrument is valid and feasible to use. The calculations of reliability test using intra-class correlation coefficient indicate that all aspects of SPS assessment are reliable with reliability criteria ranging from sufficient to high. The ICC for questioning aspect is .73 (sufficient), the ICC for predicting aspect is .88 (high), the ICC for conducting 
investigation/experiments aspect is .63 (sufficient), the ICC for data analysis aspect is .73 (sufficient), the ICC for data classifying aspect is .93 (high), and the ICC for concluding aspect is .94 (high).

The differences on improvement of MI between both groups were identified by calculating the gain score of MI before and after the learning process. The data normality was tested using Saphiro Wilk and the data homogeneity was tested using Levene test.

The data of MI and SPS were not normal and homogeny. Transformation of both data using SPSS 22 resulted normal and homogeny data. Hence, t-test was applied to determine differences of in average-normalized gain (N-gain) of MI between control and experimental groups, while one-way ANOVA was used to determine the differences of students' SPS scores among the three SPS assessment. The highest MI performance of group is determined by comparing the average-normalized gain (N-gain) of both groups, while the highest performance among three SPS assessment scores was determined by post hoc test using LSD test. The effect of MI strategy toward student's MI development was analyzed by simple linear regression. Acceptance or rejection of the hypothesis was conducted by comparing the Sig. value with the probability.

\begin{tabular}{|c|c|c|c|}
\hline \multirow[b]{2}{*}{ Group } & \multicolumn{2}{|c|}{ School Categories } & \multirow[b]{2}{*}{ Total } \\
\hline & High Achievement & Low Achievement & \\
\hline Control & 27 & 34 & 61 \\
\hline Experiment & 26 & 37 & 63 \\
\hline Total & 53 & 71 & 124 \\
\hline
\end{tabular}

Table 1. The Distribution of Sample

\begin{tabular}{|r|c|}
\hline \multicolumn{1}{|c|}{ ICC Score } & Category of the Reliability \\
\hline $.90-1.00$ & Very high \\
\hline $.80-.89$ & High \\
\hline $.60-.79$ & Sufficient \\
\hline $.00-.59$ & Poor \\
\hline
\end{tabular}

Table 2. Interpretation of ICC Score

\section{Results}

The enhancement of students' development of MI was characterized by the increase in MI scores after the learning process. Descriptive data of MI scores of both groups before and after the learning processes are presented in Table 3.

\begin{tabular}{|l|r|r|r|r|r|}
\hline \multicolumn{1}{|c|}{ Group } & Mean & Minimum & Maximum & Median & $\begin{array}{c}\text { Standard } \\
\text { Deviation }\end{array}$ \\
\hline Control & & 10 & 28 & 20 & 3.4 \\
Pre-test & 19.6 & 10 & 27 & 19 & 3.2 \\
Post-test & 19.2 & & & & \\
\hline Experimental & 19.8 & 9 & 28 & 21 & 3.3 \\
Pre-test & 20.4 & 10 & 28 & 3.7 \\
Post-test & & & & 21 \\
\hline
\end{tabular}

Table 3. Descriptive Data of Students' MI

The multiple intelligence scores of students for both groups before and after the learning process can also be seen on Figure 1. 


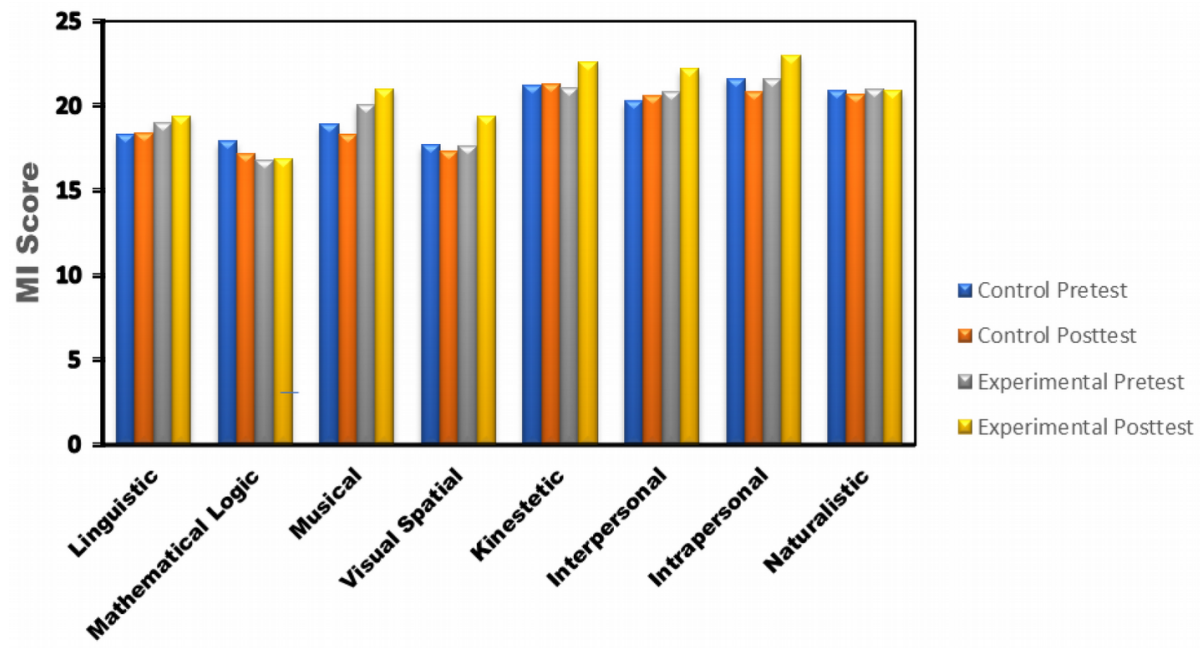

Multiple Intelligences Types

Figure 1. Mean Scores of Students' MI for Both Groups Before and After the Learning Process

In the experimental group, students' MI scores improved primarily in five types of intelligences, namely intrapersonal, interpersonal, kinesthetic, visual spatial, and musical intelligences. Linguistic intelligence was slightly increased, while the mathematical-logic intelligence tends to remain. In contrast, students' MI scores in the control group did not improve. The descriptive analysis of gain score of control and experimental groups can be seen on the Table 4 below.

As it can be seen from Table 4, the difference of gain scores was observed between control and experimental groups. The gain score of experimental group (4.09) was higher than that of control group (-.85). The gain scores difference of eight types of MI between experimental and control class were tested using t-test.

The results indicated that there were significant differences of MI gain scores between the two groups (sig. <.05). It can be stated that the difference of implemented learning strategies gives the different result of students' MI gain scores. Then, to prove the influence of learning strategy toward students' MI, simple linear regression test was implemented. The results are presented in Table 6 and Table 7.

\begin{tabular}{|l|l|r|r|r|r|r|}
\hline & N & Minimum & Maximum & Mean & Std. Deviation & \multicolumn{1}{c|}{ Variance } \\
\hline Gain_Control & 61 & -13.00 & 50.00 & -.85 & 7.90 & 62.42 \\
\hline Gain_Exp. & 63 & -11.00 & 16.00 & 4.09 & 7.08 & 100.48 \\
\hline Valid N (listwise) & 61 & & & & & \\
\hline
\end{tabular}

Table 4. MI Gain Score of Control and Experimental Groups

\begin{tabular}{|l|c|r|r|r|}
\hline & & \multicolumn{1}{|c|}{ T } & \multicolumn{1}{c|}{ df } & \multicolumn{1}{c|}{ Sig. (2-tailed) } \\
\hline MI & Equal variances assumed & 5.948 & 121 & .000 \\
\hline & Equal variances not assumed & 5.969 & 104.184 & .000 \\
\hline
\end{tabular}

Table 5. The result of MI Data t-test

\begin{tabular}{|c|r|r|r|r|}
\hline Model & \multicolumn{1}{|c|}{$\mathbf{R}$} & R Square & Adjusted R Square & Std. Error of the Estimate \\
\hline 1 & $.453^{\mathrm{a}}$ & .206 & .198 & 5.77681 \\
\hline
\end{tabular}

aPredictors: (Constant), X_Model

Table 6. The Summary of Linear Regression Model 
The summary model above indicated that learning strategy, as a predictor, correlates with MI development by correlation coefficient of .453. Coefficient of determination of .206 means that implementation of learning strategy contributes $20.6 \%$ to the development of MI. Furthermore, based on the statistical calculation, the regression model can be generated as follow.

From the constant coefficient and variable coefficient in the Table 7 , the regression model can be generated as: $\mathrm{Y}=-1.737+5.825 \mathrm{X}$. In addition, the $\mathrm{t}$-value and the significance level $(0.025<.05)$ in Table 7 shows that there is a significant effect of learning strategy toward the development of MI. It also indicates that the regression model generated is significantly used to predict the effect of learning strategy on the development of MI.

Beside the development of MI, the effectiveness of MI-based learning strategies in this study was also tested upon the improvement of students' SPS during and after learning. In the control group, SPS were not applied, therefore measurements are unnecessary. However, in the experimental group, the SPS were embedded within the MI-based learning. The development of SPS of students during and after learning was measured from the initial, the second, and the final mean scores of assessment of students' SPS. The results of the students' SPS can be seen in Table 8.

As indicated in Table 8, the SPS mean scores improved from the initial to the final assessment. This was calculated by the differences between the initial and the final score. Among the aspects of SPS, questioning skill reached the highest improvement.

The development of students' SPS was also proven by comparing the scores of the three times students' SPS assessment by using one-way ANOVA. The result of one-way ANOVA test showed that the scores of the initial, the second, and the final of students' SPS differ significantly with the sig. value $=.013$. Post hoc test using LSD performed on mean scores of the students' SPS implied no difference between mean scores of the initial and the second of students' SPS assessment with $\mathrm{p}$ value $=.188$. Conversely, there were differences between the mean scores of the initial and the final of students' SPS assessment with $\mathrm{p}$ value $=.004$, as well as between the mean score of the second and the final of students' SPS assessment with the $\mathrm{p}$ value $=.049$.

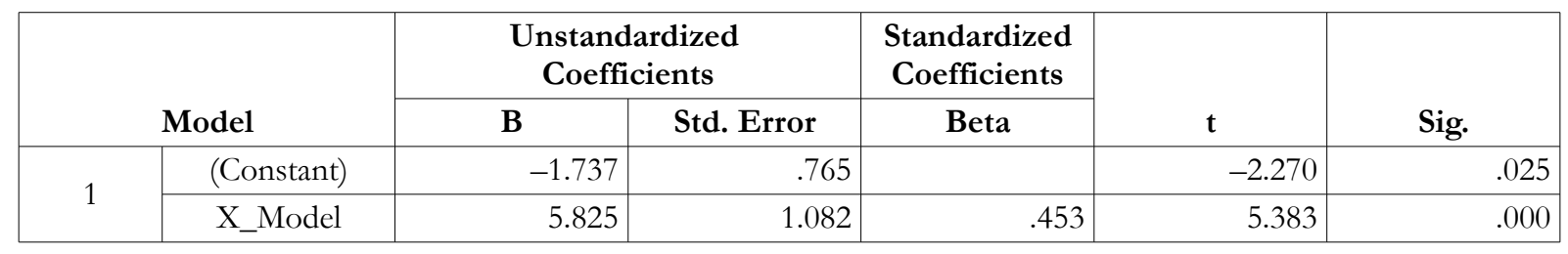

Table 7. The Linear Regression Test Result

\begin{tabular}{|c|c|c|c|c|c|c|c|c|c|}
\hline \multirow[b]{2}{*}{ Measurement } & \multirow[b]{2}{*}{$\mathbf{N}$} & \multirow[b]{2}{*}{ Min } & \multirow[b]{2}{*}{ Max } & \multicolumn{6}{|c|}{ Science Process Skills (SPS) Aspect } \\
\hline & & & & Questioning & Predicting & Analyzing & Classifying & Concluding & Mean \\
\hline Initial & 63 & 2.02 & 3.00 & 2.01 & 2.23 & 3.00 & 2.98 & 2.45 & 2.53 \\
\hline Second & 63 & 2.60 & 3.01 & 2.79 & 2.72 & 2.77 & 3.01 & 2.60 & 2.78 \\
\hline Final & 63 & 2.98 & 3.53 & 3.27 & 2.98 & 3.53 & 3.53 & 3.00 & 3.26 \\
\hline $\begin{array}{l}\text { Improvement } \\
\text { (final - initial) }\end{array}$ & - & - & - & 1.26 & 0.75 & 0.53 & 0.65 & 0.55 & 0.75 \\
\hline
\end{tabular}

Table 8. The Improvement of Students' SPS on Each Aspect

\begin{tabular}{|c|r|r|r|r|r|}
\hline & Sum of Squares & df & Mean Square & \multicolumn{1}{c|}{ F } & \multicolumn{1}{c|}{ Sig. } \\
\hline Between Groups & .033 & 2 & .016 & 6.382 & .013 \\
\hline Within Groups & .031 & 12 & .003 & & \\
\hline Total & .064 & 14 & & & \\
\hline
\end{tabular}

Table 9. The ANOVA Test Result of Students' SPS Data 


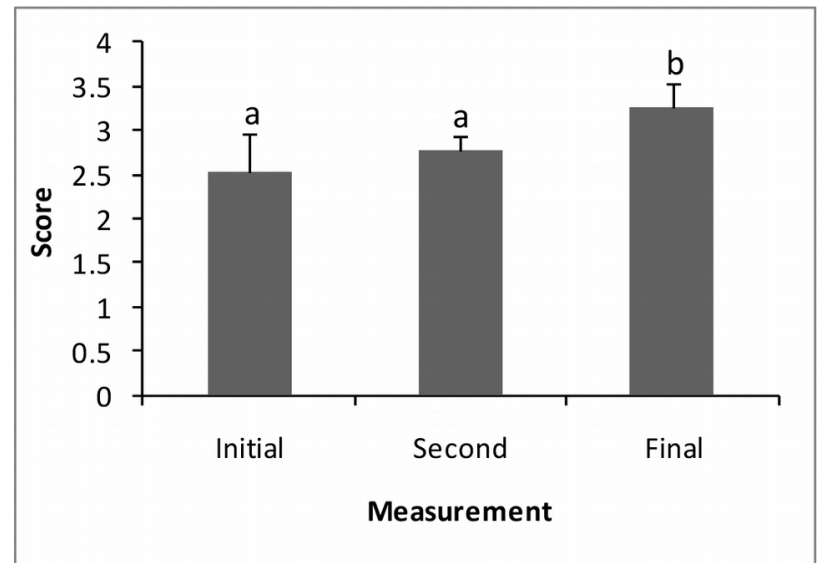

Figure 2. Improvement of students' SPS score from initial to final measurements

The post hoc test results also indicated that the mean final SPS score $(3.262 \pm 0.27)$ was significantly higher than those of initial $(2.534 \pm 0.44)$ and the second scores $(2.778 \pm 0.15)$. It means that treatment Multiple Intelligences Based Teaching Strategy has improved students' SPS.

\section{Discussion}

The study tried to reveal that both learning strategies (the traditional and the MI-strategy) do effect on MI development and science process skills of the students. The result of t-test showed that the development of students' MI in control and experimental classes was different. Likewise, the simple linear regression proved that significant relationship observed between learning strategy and the development of MI. Learning strategy contributed $20.6 \%$ on the development of students' multiple intelligence. The rest were affected by other factors. The findings are supported by Santrock (2004), Ginnis (2002), and Gaundare and Yeole (2014) who found that intelligence was affected by several factors such as genetics, nutrition, as well as environment where someone grows up. Genetic factors do provide potential for the development of one's intelligence, but other factors such as nutrition and environment also affect the development of intelligences. According to Ginnis (2002) and Santrock (2004), the environment enriched by challenges and stimulation affects the memory connection, which means affecting the intelligence level.

The regression equation $\mathrm{Y}=-1.737+5.825 \mathrm{X}$ implied that the increase of students' multiple intelligence was affected by the quality of learning strategy improvement. It was supported by Sternberg (Sternberg, 1984) in Triarchic Theory who stated that Intelligence get affected due to educational and environmental settings of an individual student. In this case, learning strategies can be assumed as an academic environment. Similarly, research conducted by Sánchez-Martín et al. (2017) proved that application of learning strategy based on MI theory in classroom enhanced not only content acquisition but also emotional intelligence.

At the beginning, the initial MI capabilities of both groups were quite similar. However, after the learning process, students in the experimental group showed an improvement in five types of intelligence, namely intrapersonal, kinesthetic, visual-spatial, interpersonal and musical. In contrast, for the control group students, only a little improvement in three types of intelligences, namely kinesthetic, interpersonal and linguistics intelligences.

This difference is caused by different students' activities in both groups. In the experimental group, the learning activities were designed to always involve MI as suggested by Gardner (1993) and Armstrong (2004). For instance, at the stage of concept introduction teacher used the real thing to stimulate visual-spatial intelligence of students. Teacher also used playing cards technique to enable interpersonal, kinesthetic and linguistics intelligence. For core activities, students did various activities involving MI such as telling daily activities, formulating questions, writing personal experiences related to the subject matter, 
designing games, writing poems and songs related to the subject matter, as well as doing mini research in the school grounds.

In contrast, the control group used common methods such as lecture, discussion, and demonstration. At the beginning of the lesson, teacher asked questions about previous lessons. While in the core activities, students observed teacher's demonstration before discussing, doing worksheets and presenting. Activities done by the students did not cover the eight aspects of MI, as in the experimental group. Only the linguistic, kinesthetic, visual-spatial and interpersonal intelligence were embedded in the activities.

There is a decrease in percentage of logical-mathematical intelligence among the experimental group students. This may be related to the item in the MI instrument regarding mathematical logical intelligences. From the 7 items, 5 items are related to numbers, calculation, and interest in mathematics, and only two items relate to the ability of logic. According to Gardner (1993) and Armstrong (2004), logical-mathematical intelligence includes not only the mathematical ability but also the ability of mathematical logic, scientific method, deductive thinking, inductive, syllogisms, and analogies. Because science learning trains more logic skills through scientific process skills, and little to do with the mathematical calculations, the actual development of intelligence was the ability of scientific logic rather than mathematical intelligence. As a result, the enhancement of mathematical logic intelligence related to scientific logic was not captured by the instrument. The decreased in mathematical logic intelligence is similar to other studies conducted by Davis (2004) and Pociask and Settles (2007).

Another cause to this phenomenon relates to learning activities. In this study, students are trained to formulate the problem, predict, experiment and observe the results, analyze the data, classify and draw conclusions. Science material characteristics have few calculations leading to little learning concepts related to numbers. As a result, the intelligence-related mathematical logic mathematical calculations were not properly developed.

The higher percentage increase of the experimental group compared to the control group as indicated by the MI gain score differences between both groups is in the tandem with the results of research by Davis (2004), Pociask and Settles (2007), Hanafin (2014), Abdi et al. (2013), Widiana and Jampel (2016), and Sánchez-Martín et al. (2017). According to them, the implementation of MI-based learning will improve several types of intelligences such as interpersonal, intrapersonal, kinesthetic, and visual spatial. Besides, implementation of MI-based learning will also enhance students' emotional and creative thinking ability.

In addition to the change on the scores of MI in general, data on the improvement of dominant intelligence is also obtained from this study. According to Gardner (1993), the dominant intelligence is important, and the increase of dominant intelligence is something that is expected in a learning process. Although in doing something, people use MI simultaneously, dominant intelligence is necessary to adjust to new conditions, such as making decisions, solving problems, as well as viewing and managing the environment. Differences in dominant intelligences of each student lead to differences in the ability to receive lessons, so it is important to recognize the dominant intelligence of students in learning process (Emmiyati, Rasyid, Rahman, Arsyad \& Dirawan, 2014; Celikoz, 2017). Knowing the level and type of student intelligence will help teacher to determine whether student is able to follow the lesson, identify the best way for each student, and predict the success or failure of the student after the lesson (Sternberg \& Grigorenko, 2003).

The enhancement of MI of students in the experimental group is due to repetitive multiple intelligence-based learning activities. The finding concurred with earlier studies conducted by Chuang et al. (2010: page 571), Eberle (2011: page 23), Nurulwahida and Azman (2014), and Nurulwahida et al. (2016). Nurulwahida et al. (2016) suggested that MI favored towards the students with treatment. The students in the treatment group improved on each multiple intelligence profile compared with students in the control group. Therefore, Nurulwahida et al. (2016) recommended that any enrichment activities conducted to enhance teaching and learning should include the MI concept. Furthermore, Yurt and Polat 
(2015) found that MI-based learning was also influenced by the duration of its implementation. The longer the activities are implemented, the higher the results will be. Research carried out by Davis (2004) and Posciak and Settles (2007) also showed that by repeatedly performing 30 minutes of Multiple Intelligence learning every day the kinesthetic, visual-spatial, and interpersonal intelligences will improve.

The increase of intrapersonal intelligence is a consequence of communicating about self-interests and habits at the stage of self-reflection, as well as through formulating questions or writing personal experiences related to the subject matter. This is further enhanced through report writing expressing understanding of concepts.

The increase of intrapersonal and interpersonal intelligence scores in the experimental group is due to MI-based instructional strategies designed to improve interpersonal and intrapersonal intelligence at once such as in pair self-reflection. In the MI-based learning strategy developed, some activities such as self-identification by filling out a MI questionnaire before the learning process, telling about themselves in pairs, evaluating the results their own work, as well as writing a set of personal experiences related to the subject matter which can sharpen the students' sensitivity in reflection so that intrapersonal intelligence increased. According to Kagan (1994), Thompson and MacDougal (2002), the use of strategies which provide opportunities for students to discuss in pairs will help students develop intrapersonal and interpersonal intelligence as well. Intrapersonal intelligence development is something that is expected to occur in a learning activity, as by having good intrapersonal intelligence, students will be successful lifelong learners.

The increase of interpersonal intelligence in the experimental group is also resulted by the use of cooperative learning strategies undertaken during the learning. Owolabi and Okebukola (2009), Talib and Bini-Kailani (2014) found that MI based learning conducted by using study group in cooperative situation provide significant different results from conventional learning. Important effect of cooperative learning was tolerance and wider acceptance of racial, cultural, and social difference, as well as cooperation and collaboration. Such attitude was one of the characters of interpersonal intelligence as proposed by Gardner (Campbell, 1997; Arends, 2008: page 6). According to Arends (2008), cooperative learning can improve cooperation which respect and support the development of interpersonal intelligence.

In addition to the MI, learning strategy effectiveness was demonstrated by the increase of SPS of students during and after the learning process. An increase on the experimental group scores of SPS in all aspects of skills trained was also found. The increasing scores trend reflected the process skill development of students taught using multiple intelligence-based learning. Active learning activities, conducted outside the classroom by implementing discovery strategy, led to good development of process skills aspects (Ting \& Siew, 2014; Sen \& Vekli, 2016).

In general, as is seen from the students' learning process skills scores, all aspects of the process skills develop well. It indicated that MI-based learning strategies train students to conduct process skills at each learning activity contributed to this increase. This is supported by research of Schwert (2004), Othman (2013), and Samsudin, Haniza, Talib and Ibrahim. (2015) which found relationship between MI and SPS, so that the application of MI based activities on one hand can influence the improvement of SPS on the other side. The finding also showed that among all process skills, questioning skill is the well-developed. At first, asking question skill is difficult for students. Almost all students need to read book first before formulating questions. Formulating questions and deepening the concept activities trained students to develop these process skills.

The development of science process skill during learning using MI-based learning is relevant with Sternberg theory (Sternberg, 1984; Sternberg \& Grigorenko, 2003) about Triarchic Intelligence theory. According to Sternberg (1984) and Sternberg and Grigorenko (2003), intelligence relates to a person's ability to process information. One type of intelligence in Triarchic theory, analytic intelligence, includes the actions of analyzing, comparing and assessing. Student activity working on worksheets that practice 
SPS such as questioning, predicting, data analyzing, classifying and concluding in this study actually trained the ability to process information. Thus, practicing the science process skill actually trains the intelligence itself. That's why students' SPS evolved along with the development of multiple students' intelligence in the study

\section{Conclusions and Implication for Future Research}

This study results important findings of the feasibility of MI-based learning strategy applied in science lessons. Based on the results, it can be concluded that there is a significantly effect of MI-strategy on the development of students MI and SPS. The implementation of MI-strategy in this study improves MI and SPS of students. Six stages of the MI based learning process, which consist of (1) self-reflection (2) introduction of the concept, (3) formulation of the question, (4) concept exploration, (5) talent show, and (6) formulation of conclusions, proved to be effective in improving five types of intelligences, namely interpersonal, intrapersonal, visual-spatial, kinesthetic and musical intelligence. The simple learning strategy steps make this strategy easy to use in the classroom, without having to create a special program as it was applied to the previous researches.

This finding also completes the results of the previous researches on the application of MI theory in learning that is aimed at improving student achievement. Although the improvement was not so high, the implementation of the MI-based learning strategy applied to science lesson not only enhances achievement, but also improves students' MI and SPS. The effects of repetitive exercises in train of SPS improved students' SPS, especially the questioning skills.

The result of this study contributes to improving the quality of science learning in the future. Learning is no longer oriented to improving academic ability only, but also attempted to improve the science process skill and potential of students.

\section{Limitations and Suggestions}

The development of intelligence is a variable that is not easily measured and observed. The use of questionnaire seems insufficient to measure the development of intelligence. It is needed other supporting instruments to measure intelligence more accurate. In this study, the students' MI slightly increased only. To increase the MI development, the research should be conducted longer and involve more subjects.

In addition, MI instrument which measure the mathematical logic should be developed further in order to focus not only to measure the intelligence of mathematics but also balanced in measuring intelligence of logic.

\section{Declaration of Conflicting Interests}

The authors declared no potential conflicts of interest with respect to the research, authorship, and/or publication of this article.

\section{Funding}

The authors received financial support by the Ministry of Research, Technology and Higher Education, Indonesia.

\section{References}

Abdi, A., Laei, S., \& Ahmadyan, H. (2013). The effect of teaching strategy based on multiple intelligences on students' academic achievement in science course. Universal Journal of Educational Research, 1(4), 281-284.

Arends, R.I. (2008). Learning to Teach (7th ed.). Translated by Helly Prajitno Soetjipto \& Sri Mulyantini Soetjipto. Yogyakarta: Pustaka Pelajar. 
Armstrong, T. (2004). Multiple Intelligences in the classroom (2nd ed.). Virginia: Association for Supervision and Curriculum Development (ASCD).

Campbell, L. (1997). How teachers interpret MI theory. Educational Leadership, 55(1), 14-19.

Celikoz, M. (2017). Multiple intelligence distribution of prospective teachers: the case at Yildiz Technical University NE University, Kemal Akman Vocational School. Journal of Education and Practice, 8(2). 206

Chuang, T.Y., Su, S.H., \& Tsao, Y.P. (2010). Using handheld gaming device to increase multiple intelligences with digital puzzle game. Wong, S.L. et al. (Eds.) Proceedings of the 18th International Conference on Computers in Education (571-573). Putrajaya, Malaysia: Asia-Pacific Society for Computers in Education.

Davis, L. (2004). Using the theory of multiple intelligences to increase fourth-grade students' academic achievement in science. An Applied Dissertation Submitted to the Fischler School of Education and Human Services Nova Southeastern University. Available at: https://eric.ed.gov/?id=ED491477

Eberle, S.G. (2011). Playing with the multiple intelligences how play helps them grow. American Journal of Play, 14(1), 19-51.

Emmiyati, N., Rasyid, M.A., Rahman, M.A., Arsyad, A., \& Dirawan, G.D. (2014). Multiple intelligences profiles of junior secondary school students in Indonesia. International Education Studies, 7(11), 103-110. https://doi.org/10.5539/ies.v7n11p103

Gagne, R.M. (1977). The Conditions of Learning Third Edition. New York: Holt Saunders International Editions.

Gardner, H. (1993). Multiple Intelligences. New York: Basic Books Hons of Learning Harper Collins Publ. Inc.

Gaundare, V.S., Yeole, A.D. (2014). An experimental study on factors affecting the multiple intelligences of MBA students with the help of informational technology. IBMRD's Journal of Management and Research, 3(1), 94-103.

Ghamrawi, N. (2014). Multiple Intelligences and ESL Teaching and Learning: An Investigation in KG II Classrooms in One Private School in Beirut, Lebanon. Journal of Advanced Academics, 25(1), 25-46. https://doi.org/10.1177/1932202X13513021

Ginnis, P. (2002). Teacher's Toolkit raise Classroom Achievement with Strategies for Every Learner. Wales: Crown House Publ Ltd.

Griggs, L., Barney, S., Brown-Sederberg, J., Collins, E., Keith, S., \& Iannacci, L. (2009). Varying pedagogy to address student multiple intelligences. Human Arcbitecture, 7(1), 55-60.

Hanafin, J. (2014). Multiple intelligences theory, action research and teacher professional development: the Irish MI project. Australian Journal of Teacher Education, 39(4), 126-142.

https://doi.org/10.14221/ajte.2014v39n4.8

Hergenhahn, B.R., \& Olson, M.H. (2009). Theories of Learning (Teori Belajar). Translated by Tri Wibowo. Jakarta: Kencana Prenada Media Group.

Kagan, S. (1994). Cooperative Learning. San Juan, CA: Kegan Cooperative Learning.

Linn, R.L., \& Gronlund, N.E. (2009). Measurement and Assessment in Teaching. Ohio: Prentice Hall.

Madkour, M., \& Mohamed, R. (2016). Identifying college students' multiple intelligences to enhance motivation and language proficiency. English Language Teaching, 9(6), 92-107.

https://doi.org/10.5539/elt.v9n6p92 
McClellan, J.A., \& Conti, G.J. (2008). Identifying the multiple intelligences of your students. Journal of Adult Education, 37(1), 13-31.

Nurulwahida, A., \& Azman, A. (2014). The effectiveness of the modular enrichment activities based on Gardner multiple intelligences and Sternberg thinking skills. Journal of Education and Practice, 5 (2), 55-62.

Nurulwahida, A., Yaacob, A., \& Shaik-Abdullah, S. (2016). The multiple intelligence-based enrichment module on the development of human potential: examining its impact and the views of teachers. Malaysian Journal of Learning and Instruction, 13(2), 175-200.

Othman., I. (2013). Elements of multiple intelligences in teaching and learning activities and the effect on students' achievement based on gender. IOSR Journal of Research \& Method in Education, 2(3), 28-32. https://doi.org/10.9790/7388-0232832

Owolabi, T., \& Okebukola, F. (2009). Improving the reading ability of science students through study groups and multiple intelligences. Online Submission, US-China Education Review, 6(2), 38-44.

Padilla, M.J. (1990). The science process skills. Research masters to the science teachers. Reston VA: NARST Publication.

Pociask, A., \& Settles, J.S. (2007). Increasing Student Achievement through Brain Based Studies. Master Thesis in Teaching and Leadership saint Xavier University Chicago, Illinois.

Samsudin, M.A., Haniza, N.M., Talib, C.A., \& Ibrahim, H.M.M., (2015). The relationship between multiple intelligences with preferred science teaching and science process skills. Journal of Education and Learning, 9(1), 53-59.

Sánchez-Martín, J., Álvarez-Gragera, G.J., Dávila-Acedo, M.A., \& Mellado, V. (2017). Teaching technology: from knowing to feeling enhancing emotional and content acquisition performance through Gardner's Multiple Intelligences Theory in technology and design lessons. Journal of Technology and Science Education, 7(1), 58-79. https://doi.org/10.3926/jotse.238

Santrock (2004). Educational Psychology (2nd ed.). Dallas: Mc Graw Hill Co.

Schwert, A. (2004). Using the Theory of Multiple Intelligences to Enhance Science Education. Thesis for The Master of Education degree in Secondary Education. Ohio: University of Toledo.

Sen, C., \& Vekli, G.S. (2016). The impact of inquiry based instruction on science process skills and self-efficacy perceptions of pre-service science teachers at a university level biology laboratory. Universal Journal of Educational Research, 4(3), 603-612. https://doi.org/10.13189/ujer.2016.040319

Slavin, R.E. (2006). Educational Psychology: Theory and Practice. Boston: Allyn and Bacon Pearson Education.

Sternberg, R.J., \& Grigorenko, E.L. (2003). Teaching for successful intelligence: principles, procedures, and practices. Journal for the Education of the Gifted, 27(2/3), 207-228.

https://doi.org/10.1177/016235320302700206

Sternberg, R.J. (1984). Toward a triarchic theory of human intelligence. Behavioral and Brain Science, 7(2), 269-287 (published online). https://doi.org/10.1017/S0140525X00044629

Streiner, D.L, Norman, G.R. (2000). Health measurement scales: A practical guide to their development and use. Oxford: Oxford University Press.

Talib, A., \& Bini-Kailani, I. (2014). Problem based learning in cooperative situation (PBLCS) and its impact on development of personal intelligence. International Journal of Evaluation and Research in Education., 3(4), 236-244. https://doi.org/10.11591/ijere.v3i4.6969

Thompson, B.R., \& MacDougall, G.D. (2002). Intelligent teaching. The Science Teacher, 69(1), 44-48. 
Ting, K.L., \& Siew, N.M. (2014). Effects of outdoor school ground lessons on students' science process skills and scientific curiosity. Journal of Education and Learning, 3(4), 96-107.

https://doi.org/10.5539/jel.v3n4p96

Widiana, I.W., \& Jampel, I.N. (2016). Improving students' creative thinking and achievement through the implementation of multiple intelligence approach with mind mapping. International Journal of Evaluation and Research in Education (IJERE), 5(3), 246-254. https://doi.org/10.11591/ijere.v5i3.4546

Yurt, E., \& Polat, S. (2015). The effectiveness of multiple intelligence applications on academic achievement: a meta-analysis. Journal of Social Studies Education Research, 6(1), 84-122.

https://doi.org/10.17499/jsser.75161

Published by OmniaScience (www.omniascience.com)

Journal of Technology and Science Education, 2018 (www.jotse.org)

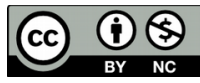

Article's contents are provided on an Attribution-Non Commercial 4.0 Creative commons International License. Readers are allowed to copy, distribute and communicate article's contents, provided the author's and JOTSE journal's names are included. It must not be used for commercial purposes. To see the complete licence contents, please visit https://creativecommons.org/licenses/by-nc/4.0/. 